\title{
Hepatoprotective activity of Adina cordifolia against ethanol induce hepatotoxicity in rats
}

\author{
*A Sharma1 , B Sangameswaran², V Jain³, M S Saluja ${ }^{1}$ \\ ${ }^{1}$ Research Scholars, Department of Pharmacy, Suresh Gyan Vihar University, Jaipur, Rajasthan, India \\ ${ }^{2}$ Principal, SSM College of Pharmacy, Jambai Village, Bhavani Taluk, Erode-638 312, Tamil Nadu, India \\ ${ }^{3}$ TIT College of Pharmacy, Bhopal, India
}

\begin{abstract}
The acetone $(A E A C)$ and aqueous extracts $(A Q E A C)$ of Adina cordifolia, belonging to the family Rubiaceae, were studied for hepatoprotective activity against Wister rats with liver damage induced by ethanol. It was found that $A E A C$ and $A Q E A C$, at a dose of $500 \mathrm{mg} / \mathrm{kg}$ body weight exhibited hepatoprotective effect by lowering the Serum Glutamate Pyruvate Transaminase (SGPT), Serum Glutamate Oxaloacetate Transaminase (SGOT), alkaline phosphate and total bilirubin to a significant extent and also significantly increased the levels of total protein. The hepatoprotective activity was also supported by histopathological studies of liver tissue. Since results of biochemical studies of blood samples of ethanol treated rats showed significant increase in the levels of serum enzyme activities, reflecting the liver injury caused by ethanol and blood samples from the animals treated with $A E A C$ and $A Q E A C$ showed significant decrease in the levels of serum markers, indicating the protection of hepatic cells against ethanol induced hepatocellular injury. The effects of $A E A C$ and $A Q E A C$ were comparable with standard drug silymarin.
\end{abstract}

Key Words: Silymarin, SGOT, SGPT, alkaline phosphate, total bilirubin, total protein.

\section{INTRODUCTION}

Liver is one of the largest organs in human body and the chief site for intense metabolism and excretion. So it has a surprising role in the maintenance, performance and regulating homeostasis of the body. It is involved with almost all the biochemical pathways to growth, fight against disease, nutrient supply, energy provision and reproduction (Ward and Daly, 1999). The major functions of the liver are carbohydrate, protein and fat metabolism, detoxification, secretion of bile and storage of vitamin. Thus, to maintain a healthy liver is a crucial factor for overall health and well being. But it is continuously and variedly exposed to environmental toxins, and abused by poor drug habits, and alcohol and prescribed \& over-the-counter drug which can eventually lead to various liver ailment like hepatitis, cirrhosis and alcoholic liver disease

\footnotetext{
*Corresponding Author:

Ajay Sharma, Assistant professor

Department of Pharmacy

Suresh Gyan Vihar University

Jagatpura, Jaipur, Rajasthan, India.

E-mail: ajaypharma85@gmail.com

Contact No.: +91- 09827687111
}

(Sharma et al., 1991; Subranonium \& Pushpangadan, 1999). Thus liver diseases are some of the fatal disease in the world today. They pose a serious challenge to international public health. Modern medicines have little to offer for alleviation of hepatic diseases and it is chiefly the plant based preparations which are employed for their treatment of liver disorders. But there are not much drug available for the treatment of liver disorders (Karan et al., 1999; Chaterrjee, 2000). Therefore, many folk remedies from plant origin are tested for its potential antioxidant and hepatoprotective liver damage in experimental animal model (Rubinstein, 1962; Suja et al., 2002). The medicinal use of many plants (as hepatoprotectives) like Andrographis paniculata, Azadirachta indica, Cassia fistula, Elephantopus scaber, Hibiscus rosasinensis, Phyllanthus debilis, Picrorrhiza kurroa has been reported in the literature (Rajesh et al., 2001; Anandan et al., 1999).

Adina cordifolia, (Rubiaceae) (commonly known as Haridru) is found throughout central and south India to Srilanka. The 7-hydroxycoumarin-1 and 7- $\beta$-Dglucosylcoumarin-2 were isolated from the root bark 
of Adina cordifolia, having antiamoebic activity (Firdoos et al., 2009). According to ayurveda, the bark of this plant is used in liver disorders (Yoganarasimhan 1996). Adina cordifolia was also reported for its antiulcer potential activity (Kasinadhuni et al., 1999), antifertility activity (Sabir et al., 1970), anti- inflammatory and anti-nociptive activity (Jain et al., 2006).

\section{MATERIALS AND METHODS}

Procurement and Authentification of the Plant

The leaves of Adina cordifolia were collected from local area of village Ingoriya, Ujjain, Madhya Pradesh and it was authenticated by Dr. S. K. Billore, at Vikram University, Ujjain, Madhya Pradesh. The voucher specimen (MIPS/N/012/2010) was deposited at Department of Pharmacognosy, Mahakal Institute of Pharmaceutical Studies, Ujjain, Madhya Pradesh for future reference.

\section{Preparation of extracts of Adina cordifolia}

The powdered leaves $(500 \mathrm{~g})$ were extracted by using acetone by sequentially extracted using petroleum ether, chloroform, acetone and ethanol in Soxhlet apparatus. Whereas aqueous extract was obtained by cold maceration processes. After about forty siphons of each solvent extraction step, the materials were concentrated by evaporation (Farnsworth, 1966).

\section{Animals}

Wistar albino rats (150-200g) used in studies, was procured from Central Drug Research Institute, Lucknow, India. The animals were fed with standard pellet diet (Hindustan lever Ltd. Bangalore) and water ad libitum. All the animals were acclimatized for a week before use. The experimental protocols were approved by Institutional Animal ethics Committee after scrutinization. Animals were received the drug by oral gavage tube. All the animals were care of under ethical consideration as per the CPCSEA guidelines (CPCSEA, 2003) with regular inspections of rats. The laboratory conditions duly undertaken by registered veterinary practitioner.

\section{Chemicals}

All the chemicals and solvents were of analytical grade. Silymarin was obtained as gift sample from Micro Lbs, Goa, India. Standard kits for SGOT,
Table 1: Evaluation of hepatoprotective activity by ethanol induced hepatotoxicity in rats.

\begin{tabular}{|c|c|}
\hline Group & Treatment \\
\hline I & $\begin{array}{l}\text { Received water }(5 \mathrm{ml} / \mathrm{kg} \text {. p.o) for } 21 \text { days } \\
\text { once daily, and served as normal control. }\end{array}$ \\
\hline I \& II & $\begin{array}{l}\text { Received water ( } 5 \mathrm{ml} / \mathrm{kg} \text {. p.o) for } 21 \text { days } \\
\text { once daily and } 40 \% \text { ethanol (v/v, } \\
2.0 \mathrm{ml} / 100 \mathrm{~g} \text { body wt, p.o.) for } 21 \text { days. }\end{array}$ \\
\hline I, II \& III & $\begin{array}{l}\text { Received standard drug silymarin ( } 25 \\
\mathrm{mg} / \mathrm{kg} \text {. p.o.) for } 21 \text { days once daily and } \\
40 \% \text { ethanol (v/v, } 2.0 \mathrm{ml} / 100 \mathrm{~g} \text { body wt, p.o.) } \\
\text { for } 21 \text { days. }\end{array}$ \\
\hline I, II, III \& IV & $\begin{array}{l}\text { Received AEAC ( } 500 \mathrm{mg} / \mathrm{kg}) 21 \text { days once } \\
\text { daily and } 40 \% \text { ethanol }(\mathrm{v} / \mathrm{v}, 2.0 \mathrm{ml} / 100 \mathrm{~g} \\
\text { body wt, p.o.) for } 21 \text { days. }\end{array}$ \\
\hline V & $\begin{array}{l}\text { Received AQEAC ( } 500 \mathrm{mg} / \mathrm{kg}) 21 \text { days } \\
\text { once daily and } 40 \% \text { ethanol (v/v, } \\
2.0 \mathrm{ml} / 100 \mathrm{~g} \text { body wt, p.o.) for } 21 \text { days. }\end{array}$ \\
\hline
\end{tabular}

Rats were divided into 5 groups of 6 animals $(n=6)$ in each (Kapoor et al., 1994)

SGPT and ALP etc. were obtained from Span Diagnostics Ltd., India.

\section{Acute toxicity studies}

Healthy Wistar albino rats of either sex weighing 100-150 g maintained under standard laboratory conditions were used for acute oral toxicity test according to Organization for Economic Cooperation and Development guidelines 423. Animals were observed individually at least once during first $30 \mathrm{~min}$ after dosing, periodically during first $24 \mathrm{~h}$ (with special attention during the first $4 \mathrm{~h}$ ) and daily thereafter for period of 3 days (OECD, 1996). Observations were done daily for changes in skin and fur, eyes, mucus membrane (nasal), respiratory rate, circulatory signs (heart rate), autonomic effect (salivation, lacrimation, perspiration, urinary incontinence and defecation) and central nervous system (drowsiness, gait, tremors and convulsion) changes.

\section{Assessment of hepatoprotective activity}

After $24 \mathrm{~h}$ of ethanol administration, on $22^{\text {nd }}$ day, blood was obtained from animals by puncturing retro orbital plexus. Blood samples were allowed to clot for $45 \mathrm{~min}$ at room temperature. Serum was separated by centrifugation at $2500 \mathrm{rpm}$ at $30^{\circ} \mathrm{C}$ for $15 \mathrm{~min}$ and utilized for the estimation of various biochemical parameters including SGOT \& SGPT (Reitman et al., 
Table 2: Effect of $A E A C$ and $A Q E A C$ on ethanol induced hepatotoxicity in rats.

\begin{tabular}{|c|c|c|c|c|c|}
\hline Treatment/ Dose & $\operatorname{SGPT}(\mu / \mathrm{min} / \mathbf{l})$ & $\operatorname{SGOT}(\mu / \mathrm{min} / \mathbf{l})$ & $\operatorname{ALP}(\mu / \mathrm{min} / 1)$ & Total Bilirubin mg/dl & Total Protein gm/d] \\
\hline Normal & $62.0 \pm 3.71$ & $168.04 \pm 2.80$ & $190.0 \pm 8.01$ & $0.38 \pm 0.06$ & $9.57 \pm 0.24$ \\
\hline Induced(ethanol) & $98.75 \pm 8.86^{*}$ & $258.42 \pm 4.24^{*}$ & $244.76 \pm 8.82^{*}$ & $6.42 \pm 8.66^{*}$ & $5.40 \pm 8.46^{*}$ \\
\hline $\begin{array}{l}\text { Standard (silymarin } \\
25 \mathrm{mg} / \mathrm{kg} \text { ) }\end{array}$ & $63.76 \pm 4.63^{* *}$ & $176.28 \pm 8.47^{* *}$ & $194.27 \pm 4.27^{* *}$ & $0.45 \pm 2.82^{* *}$ & $9.81 \pm 4.26^{* *}$ \\
\hline$A E A C(500 \mathrm{mg} / \mathrm{kg})$ & $79.88 \pm 8.22^{* *}$ & $196.28 \pm 4.24^{* *}$ & $210.46 \pm 8.22^{* *}$ & $0.68 \pm 4.62^{* *}$ & $8.28 \pm 8.12^{* *}$ \\
\hline$A Q E A C(500 \mathrm{mg} / \mathrm{kg})$ & $68.28 \pm 6.76^{* * *}$ & $186.84 \pm 4.26^{* * *}$ & $198 \pm 8.44^{* * *}$ & $0.56 .0 \pm 2.20^{* * *}$ & $6.18 \pm 7.48^{* * *}$ \\
\hline
\end{tabular}

Values are mean $\pm S E M, n=6$. (One way ANOVA Followed by Dunnette multiple Comparisons test)

Statistically significance of ${ }^{* *} \mathrm{P}<0.01,{ }^{* * *} \mathrm{P}<0.001$, when compared with respective control

1957), ALP (Kind et al., 1954), serum bilirubin (Amour et al., 1965) and serum protein (Lowry et al., 1951) After collection of blood samples, the animals were sacrificed under deep ether anesthesia.

Morphological parameters like weight of animals, weight of liver have also been used to evaluate the protective effect of the drug. Hepatoprotective chemical causes loss in liver weight/100 gm body weight of rats (Avadhoot et al., 1991; Bhanwra et al., 2000).

\section{Histopathology studies}

A portion of liver tissue of all the animal groups was excised and then washed with normal saline. The liver tissues were fixed in $10 \%$ buffered neutral formalin for $48 \mathrm{~h}$ and then with bovine solution for 6 $\mathrm{h}$ and were then processed for paraffin embedding. By using a microtome, sections of 5 micron thickness were taken and stained with hematoxylin and eosin. These sections were examined under light microscope (Model No: 138, Linco Pvt Ltd, Ambalacantt, Punjab, India) using a magnification of 100X (Mankani et al., 2005).

\section{Statistical Significance (GraphPad Prism)}

The results of the study were expressed as mean \pm SEM, $\mathrm{n}=6$. ANOVA (Gennaro et al., 1995) was used to analyze and compare the data, followed by Dunnet's (Dunnet et al., 1964) test for multiple comparisons.

\section{RESULTS}

\section{Acute toxicity study}

There was no mortality found amongst the graded dose groups of animals and they did not show any toxicity or behavioral changes at a dose level of 5000 $\mathrm{mg} / \mathrm{kg}$. This finding suggests that the $A E A C$ and $A Q E A C$ were safe or non-toxic to rats and hence doses of $500 \mathrm{mg} / \mathrm{kg}$, p.o. were selected for the study.

Effect of AEAC and AQEAC on serum marker enzyme levels

There was a significant elevation in the levels of serum marker enzymes like SGOT, SGPT etc, content of ethanol intoxicated animals. In contrast, pretreatment with $A E A C$ and AQEAC $(500 \mathrm{mg} / \mathrm{kg}$, po) and silymarin (25 mg/kg, po) exhibited an ability to counteract the hepatotoxicity by decreasing serum marker enzymes. The results were showed in table 2 .

\section{Effect of $A E A C$ and $A Q E A C$ on biochemical parameters}

In ethanol treated groups, there was a significant increase in total bilirubin and significant reduction in total protein content. Whereas, pretreatment with $A E A C$ and $A Q E A C(500 \mathrm{mg} / \mathrm{kg}, \mathrm{po})$ caused significant reduction in total bilirubin and significant increase in total protein. The results were showed in table 2.

\section{Effect of $A E A C$ and $A Q E A C$ on liver weight}

Ethanol intoxicated group of animals, weight of the liver was significantly increased, but it was normalized in $A E A C$ and $A Q E A C(500 \mathrm{mg} / \mathrm{kg}$, po) treated groups of animals. A significant reduction in liver supports this finding. The results were showed in table 3.

\section{Histopathology}

Histopathological studies of liver also provided a supportive evidence for biochemical analysis. Histological changes such as steatosis (fatty changes in hepatocytes) and perivenular fibrosis were 
Table 3: Effect of $A E A C$ and $A Q E A C$ on liver weight variation of ethanol induced hepatotoxicity in rats.

\begin{tabular}{ll}
\hline Treatment & Liver weight in $\mathbf{g m} / \mathbf{1 0 0 g}$ \\
\hline Normal & $6.84 \pm 0.06$ \\
Induced (Ethanol) & $8.24 \pm 0.28^{*}$ \\
silymarin $25 \mathrm{mg} / \mathrm{kg}$ & $7.06 \pm 0.48^{* * *}$ \\
$A E A C(500 \mathrm{mg} / \mathrm{kg})$ & $8.10 \pm 2.48^{* *}$ \\
$A Q E A C(500 \mathrm{mg} / \mathrm{kg})$ & $7.20 \pm 0.76^{* * *}$ \\
\hline
\end{tabular}

Values are mean \pm SEM, $n=6$. (One way ANOVA followed by Dunnette multiple comparisons test)

Statistically significance of ${ }^{* *} \mathrm{P}<0.01,{ }^{* *} \mathrm{P}<0.001$, when compared with respective control

observed in ethanol treated (toxic) control group. Both the plant extracts has prevented these histological changes. The results were showed in figure 1a-e.

\section{DISCUSSION}

There are many factors which are responsible for the liver damage or injuries such as chemicals and drugs. In the present study ethanol was used to induce hepatotoxicity, since it is clinically relevant. Ethanol produces a constellation of dose related deleterious effects in the liver (Leo et al., 1982). The majority of ethanol is metabolized in the liver and individuals who abuse alcohol by routinely drinking 50-60 g (about 4 to 5 drinks) of ethanol per day are at risk for developing alcoholic liver disease (Zakhari et al., 2007). In addition, both acute and chronic ethanol administration cause enhanced formation of cytokines, especially TNF-alpha by hepatic Kupffer cells, which have a significant role in liver injury (Zhou et al., 2003; Thurman et al., 1998; Tsukamoto et al., 2001). Besides the development of fatty liver (steatosis), another early sign of excessive ethanol consumption is liver enlargement and protein accumulation, both of which are common findings in alcoholics and heavy drinkers (Baraona et al., 1975; Baraona et al., 1977).

Elevated levels of serum glutamic oxaloacetic transaminase (SGOT) and serum glutamic pyruvic transaminase (SGPT) are indications of hepatocellular injury (Yue et al., 2006). In the present study $A E A C$ and $A Q E A C$ at a dose of $500 \mathrm{mg} / \mathrm{kg}$, po caused a significant inhibition in the levels of SGOT and SGPT towards the respective normal range and this is an indication of stabilization of plasma membrane as well as repair of hepatic tissue

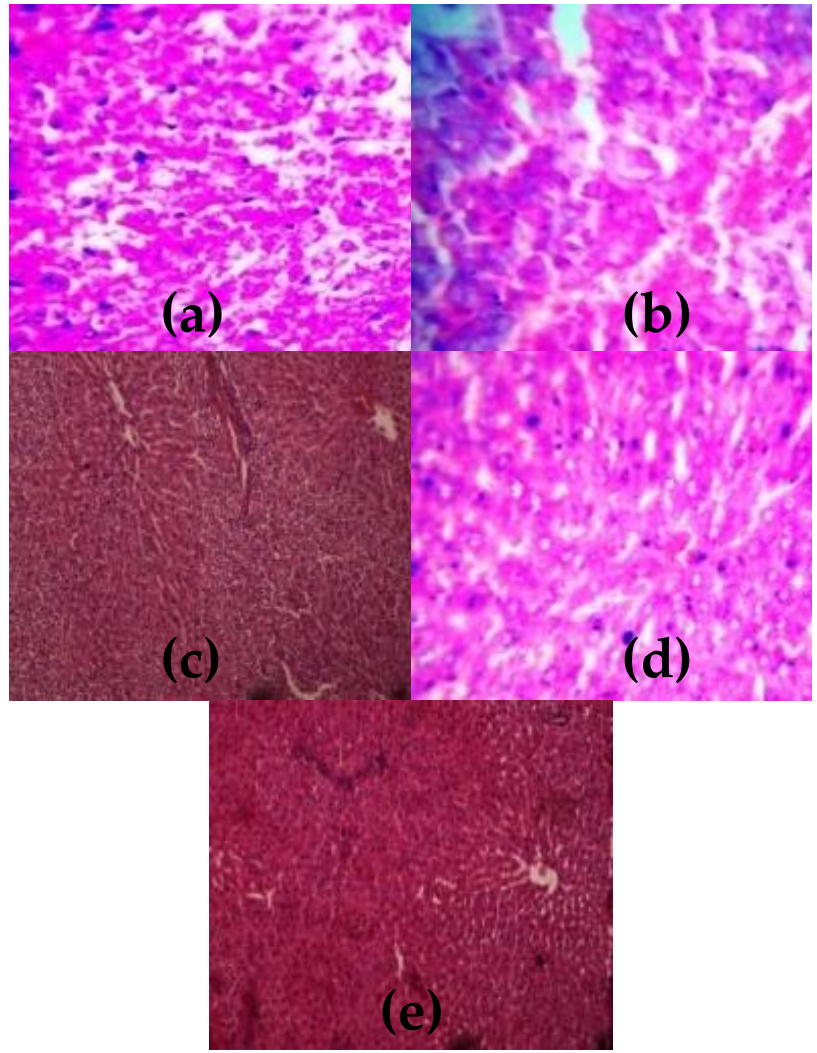

Figure 1: Histopatholocigal Study of liver;

(a) Normal control, (b) ethanol induce hepatotoxicity, (c) treated with AEAC, (d) treated with silymarin, (e) treated with AQEAC.

damage caused by ethanol. On the other hand suppression of elevated ALP activities with concurrent depletion of raised bilirubin level and an increase in the total plasma protein content suggests the stability of biliary dysfunction in rat liver during hepatic injuries with toxicants (Mukherjee et al., 2002).

These results indicate that $A E A C$ and $A Q E A C$ preserved the structural integrity of the hepatocelluar membrane and liver cell architecture damaged by ethanol which was confirmed by histopathological examination.

Phytochemical screening revealed that $A E A C$ and $A Q E A C$ contains active pharmacological constituents such as flavonoids, alkaloids, phytosterols and phenolic compounds. However, it has been already reported that such phytoconstituents like phenolic compounds, flavonoids, tannins (Paya et al., 1993) are known to possess hepatoprotective activity in 
various experimental models. Therefore it has been suggest that the hepatoprotective activity shown by the $A E A C$ and $A Q E A C$ can be because of these active phytoconstituents present in the plant which is being also confirmed by the biochemical and histological parameters. The aqueous extract has shown more promising effect as compared to ethanol extracts of leaves of Adina cordifolia. The plant selected for the present study has demands for further phytochemical as well as pharmacological research such isolation of principle active phytoconstituents, evaluation of various pharmacological activities. Out of these aspects some respective parameters are already in process at our organization.

\section{REFERENCES}

Amour FF D', Blood FR, Belden DA. (1965) The manual for laboratory work in Mammalian Physiology. The University of Chicago Press, Chicago, 126-128.

Anandan R, Deepa Rekha R, Devaki T. (1999) Protective effect of Picrorrhiza kurroa on mitochondrial glutathione antioxidant system in D-galactosamine- induced hepatitis in rats. Current Science 76: 1543-5.

Avadhoot V, Rana V. (1991) Hepatoprotective effect of Vitex negundo against carbon tetrachloride-induced liver damage. Arch Pharmacy Research 14(1): 96-98. [DOI]

Baraona E, Leo MA, Borowsky SA, Lieber CS. (1975) Alcoholic hepatomegaly: accumulation of protein in the liver. Science 190: 794-795. [DOI]

Baraona E, Leo MA, Borowsky SA, Lieber CS. (1977) Pathogenesis of alcohol-induced accumulation of protein in the liver. Journal of Clinical Investment 60: 546-554. [DOI]

Bhanwra V, Singh V, Khosla V. (2000) Effect of Azadirachta indica (Neem) leaf aqueous extract on paracetamolinduced liver damage in rats. Indian Journal of Physiolology and Pharmacology 44(1): 64-68.

Chaterrjee TK. (2000) Medicinal Plants with Hepatoprotective Properties. Herbal Options. Books and Applied Allied (P) Ltd., Calcutta, 143.

CPCSEA. (2003) Indian Journal pharmacology 35: 257-274.

Dunnet CW. (1964) New Tables for Multiple Comparisons with a Control. Biometrics 20: 482-491. [DOI]

Farnsworth NR. (1966) Biological and phytochemical screening of plants, Journal Pharmaceutical Science 55: 225-76. [DOI]

Firdoos I, Bhat AR, Azam A. (2009) Antiamoebic coumarins from the root bark of Adina cordifolia and their new thiosemicarbazone derivatives. European Journal of Medicinal Chemistry, 44(5): 2252-2259. [DOI]
Gennaro AR. (1995) Remington: The science and practice of pharmacy, vol. I, 19th ed, Mack Publishing Company, Easton (PA), pp.111.

Jain AP, Pawar RS, Singhai A. (2006) Anti-inflammatory and anti-nociptive activity of Adina cordifolia bark. Nigerian Journal of Natural Products and Medicines 10: 90-93.

Kapoor V, Pillai K, Hussian SZ, Balani DK. (1994) Hepatoprotective activity of "jigrine" on liver damage caused by alcohol, Carbontetrachloride and paracetamol in rats. Indian Journal of Pharmacology 26: 35-40.

Karan M, Vasisht K, Handa SS. (1999) Antihepatotoxic activity of Swertia chirata on carbon tetrachloride induced hepatotoxicity in rats. Phytotherapy Research 13: 24-30. [DOI]

Kasinadhuni VRR, Rajashekhar G, Rajagopalan R, Sharma VM, Vamsi Krishna C, SairamP, Sai Prasad G, Sadhukhan S, Gangadhar Rao G. (1999) Antiulcer potential of Haldina cordifolia. Fitoterapia 70(1): 93-95. [DOI]

Kind PRN, King EJ. (1954) Estimation of plasma phosphatase by determination of hydrolysed phenol with aminoantipyrine. Journal Clinical Pathology 7(4): 322-326. [DOI]

Leo MA, Arai M. (1982) Hepatotoxicity of vitamin A and ethanol in the rat. Gastroenterology 82: 194-205.

Lowry OH, Rosebrough NJ, Farr AL, Randall RJ. (1951) Protein measurement with the Folin phenol reagent. Journal of Biological Chemistry 193: 265-275.

Mankani KL, Krishna V, Manjunatha BK, Vidya SM, Singh SJ, Manohara YN, Raheman A, Avinash KR. (2005) A review of natural products with hepatoprotective Activity. Indian Journal of Pharmacology 37(3): 165-168.

Mukherjee PK. (2002) Quality control of herbal drugs, 1st ed, Business Horizons Pharmaceutical Publication, New Delhi, pp. 531.

OECD. (1996) Guidelines for the testing of chemicals, Test no.423, Acute Oral Toxicity -Acute Toxic Class Method.

Paya M, Ferrandiz ML, Sanz MJ, Alcaraz MJ. (1993) Effects of phenolic compounds on bromobenzene-mediated hepatotoxicity in mice. Xenobiotica 23: 327. [DOI]

Rajesh MG, Latha MS. (2001) Hepatoprotection by Elephantopus scaber Linn in CCl4- induced liver injury. Indian Journal of Physiology and Pharmacology 45: 481-6.

Reitman S, Frankel S. (1957) A colorimetric method for the determination of serum glutamic oxalacetic and glutamic pyruvic transaminases. American Journal Clinical Pathology 28: 56-63.

Rubinstein D. (1962) Epinephrine release and liver glycogen levels after carbon tetrachloride administration. American Journal of Physiology 203: 1033-1037.

Sabir M, Razdan MK. (1970) Antifertility study with leaf extracts of Adina cordifolia. Indian Journal of Physiology and Pharmacology 14(3): 209-210. 
Sharma A, Chakraborti KK, Handa SS. (1991) Antihepatotoxic activity of some Indian herbal formulations as compared to silymarin. Fitoterapia 62: 229-235.

Subramonium A, Pushpangadan P. (1999) Development of Phytomedicines for liver diseases. Indian J. Pharmacol 31: 166-175.

Suja SR, Latha PG, Pushpangadan P, Rajasekharan S. (2002) Aphrodisiac property of Helminthostachys zeylanica in mice. Journal of Tropical Medicinal Plants 3: 191-195.

Thurman RG. (1998) Alcoholic liver injury involves activation of Kupffer cells by endotoxin. American Journal of Physiology 275: 605-611.

Tsukamoto H, Takei Y, McClain CJ, Shimizu H, Sato N, Thurman R. (2001) How is the liver primed or sensitized for alcoholic liver disease. Alcohol Clinical Express Research 25: 171-181. [DOI]
Ward FM and Daly MJ. (1999) “Hepatic Disease. In: Clinical Pharmacy and Therapeutics (Walker R.and C.Edwards Eds.)". Churchill Livingstone, New York. pp. 195-212.

Yoganarasimhan SN. (1996) Medicinal plant of India.vol-1 Karnataka. Interline publishing pvt.ltd, Bangalore, pp 232.

Yue M, Yu CH, Ren K, Chen W, Li Y. (2006) Transient elevation of hepatic enzymes in volunteers after intake of alcohol. Hepatobiliary and Pancreatic Diseases International 5(1): 52-55.

Zakhari S, Li TK. (2007) Determinants of alcohol use and abuse: Impact of quantity and frequency patterns on liver disease. Hepatology 46: 2032-2039. [DOI]

Zhou Z, Wang L, Song Z, Lambert JC, McClain CJ, Kang YJ. (2003) A critical involvement of oxidative stress in acute alcohol-induced hepatic TNF-alpha production. American Journal of Pathology 163: 1137-1146. [DOI] 